\title{
Johann Heinrich Cohausen (1665-1750), Salt Iatrochemistry, and Theories of Longevity in his Satire, Hermippus Redivivus (1742)
}

\author{
ANNA MARIE ROOS*
}

\begin{abstract}
Introduction
Johann Heinrich Cohausen (1665-1750) was a physician and well-known author in the Germanies, France, and England (Figure 1). He was best known for medical satire such as the Pica Nasi, a Latin parody on snuff in which Apollo ordered Mercury to confiscate the noses of snuff-takers. When the satyrs returned them, the desperate victims grabbed the wrong noses and were unrecognizable (Figure 2). ${ }^{1}$ The subject of this article however is Cohausen's last and most famous medical satire, his Hermippus redivivus (1742), a treatise on the prolongation of life. Studies of Cohausen and the Hermippus have been largely antiquarian; the only scholarly works are a French dissertation concerning his medical biography done in 1900 and a short German bibliographic study. ${ }^{2}$ Because Cohausen has been primarily known for medical satire, his large number of serious treatises on iatrochemistry and medicine, which served as the basis for his more humorous works, have been largely unexamined. This paper will thus demonstrate that Cohausen's Hermippus and its comedic presentation of longevity had a profound reliance on earlier scholarly works of his that analysed the theories of the seventeenth-century chymist and physician Jean Baptiste van Helmont (1577-1634). ${ }^{3}$ In particular, Cohausen utilized van Helmont's belief that volatile salts (salts that had an odour or that decomposed readily on heating)
\end{abstract}

(C) Anna Marie Roos 2007

*Anna Marie Roos, PhD, Wellcome Unit for the History of Medicine, 45-47 Banbury Road, Oxford OX2 6PE, UK.

I would like to thank Mark Harrison, Director of the Wellcome Unit, Oxford University, for giving me the opportunity to be a visiting fellow during my sabbatical year from the University of Minnesota, the institution which also gave me the time needed to write this article. I am also grateful for the help of Sue Killoran, Librarian of Harris Manchester College, Oxford University, staff at the Bodleian Library, British Library, and the librarians and interlibrary loan department at the University of Minnesota Duluth. My thanks also to the anonymous reviewers and editors of Medical History for their suggestions for the improvement of my article.

\footnotetext{
${ }^{1}$ Johann Heinrich Cohausen, Dissertatio satyrica physico-medico-moralis de pica nasi, sive tabaci sternutatorii, Amsterdam, J Oosterwyk, 1716.
}

\footnotetext{
${ }^{2}$ An antiquarian study is found in S Baring-Gould, 'Hermippus Redivivus', in idem., Curiosities of olden times, New York, Thomas Whittaker, 1896, pp. 13552. A scholarly dissertation about Cohausen was written by A Beauvois, 'Un practicien allemand au XVIIIe siècle: Jean-Henri Cohausen (1665-1750)', $\mathrm{PhD}$ thesis, University of Paris, April 1900. My thanks to Mrs Jane Fleeson for translating this work from the French. There is a short bibliographical study of Cohausen in Hermann Paal, Johann Heinrich Cohausen, 1665-1750. Leben und Schriften eines bedeutenden Arztes aus der Blütezeit des Hochstiftes Münster, mit kulturhistorischen Betrachtungen, Jena, G Fischer, 1931.

${ }^{3}$ The use of "chymist" and "chymistry" is deliberate; I am using these terms as suggested by William R Newman and Lawrence M Principe in 'Alchemy vs. chemistry: the etymological origins of a historiographic mistake', Early Sci. Med., 1998, 3: 3265, p. 41: "since all the topics we today associate under the two terms 'alchemy' and 'chemistry' were indiscriminately classed under either term by early
} 


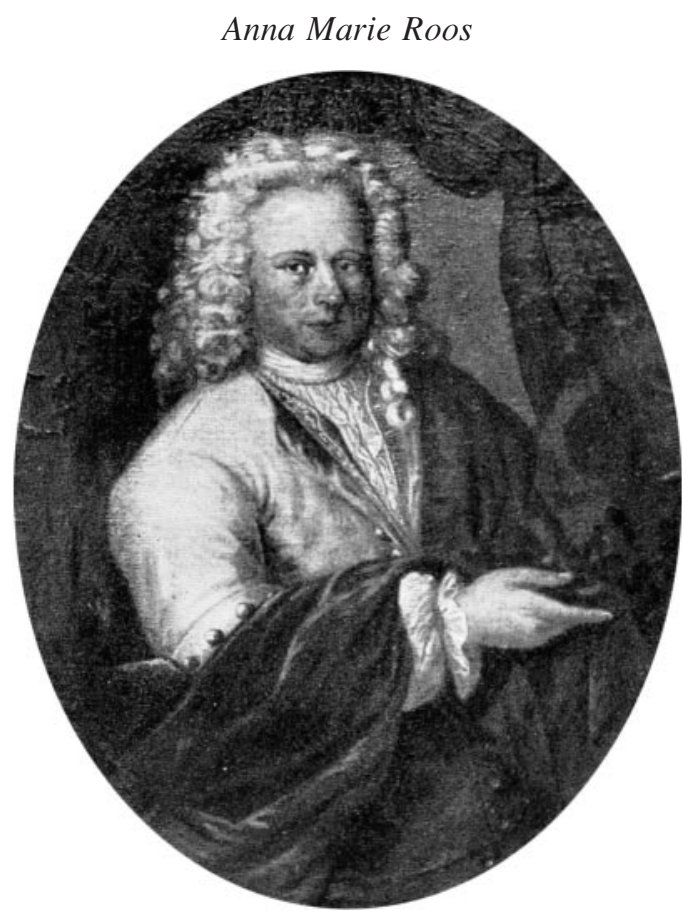

Figure 1: Portrait of Johann Heinrich Cohausen (1665-1750). (By permission of the Wellcome Library, London.)

composed the vital spirit or the breath of both animals and plants; it was these volatile salts in the breath, more prevalent in the young, which Cohausen argued would extend life's duration. ${ }^{4}$ Cohausen's ideas in the Hermippus were also influenced by Sanctorius' (15611636) studies of ambient air and bodily secretions, and to a lesser degree by the Leiden physician Hermann Boerhaave (1668-1738).

Although Cohausen's scholarly treatises demonstrated that he was committed to chymical medicine in his own practice, he could still with trenchant wit poke fun at the pursuit of immortality. His work was within a revived literary tradition of alchemical satire, which, as Stanton Linden has showed, occurred at the end of the seventeenth century in England, and was continued in the Germanies. ${ }^{5}$ Cohausen admitted at the end of the Hermippus that he wrote it in a humorous vein for his own enjoyment (and probably in hope of book sales), but he also knew that recently accepted medical beliefs and applications formed the basis of

modern writers, we advocate the use of the archaicallyspelt chymistry to express inclusively the undifferentiated domain. This usage will help evade the potential arbitrariness and consequent misunderstandings evoked when the terms 'alchemy' and 'chemistry' are used casually in reference to activities between the time of the Reformation and the end of the seventeenth century."

${ }^{4}$ A G Debus, 'The Paracelsian aerial niter', Isis, March 1964, 55 (1): 43-61, p. 58.

\footnotetext{
${ }^{5}$ Stanton J Linden, Darke hierogliphicks: alchemy in English literature from Chaucer to the Restoration, Lexington, University Press of Kentucky, 1996.

Linden argues that Chaucer begins "a long tradition of alchemical satire" that is interrupted by a "new tradition of spiritual alchemy" in the poetry of Donne, Herbert, and others, before a return in the work of Butler to the earlier satirical tradition at the turn of the
} century. 


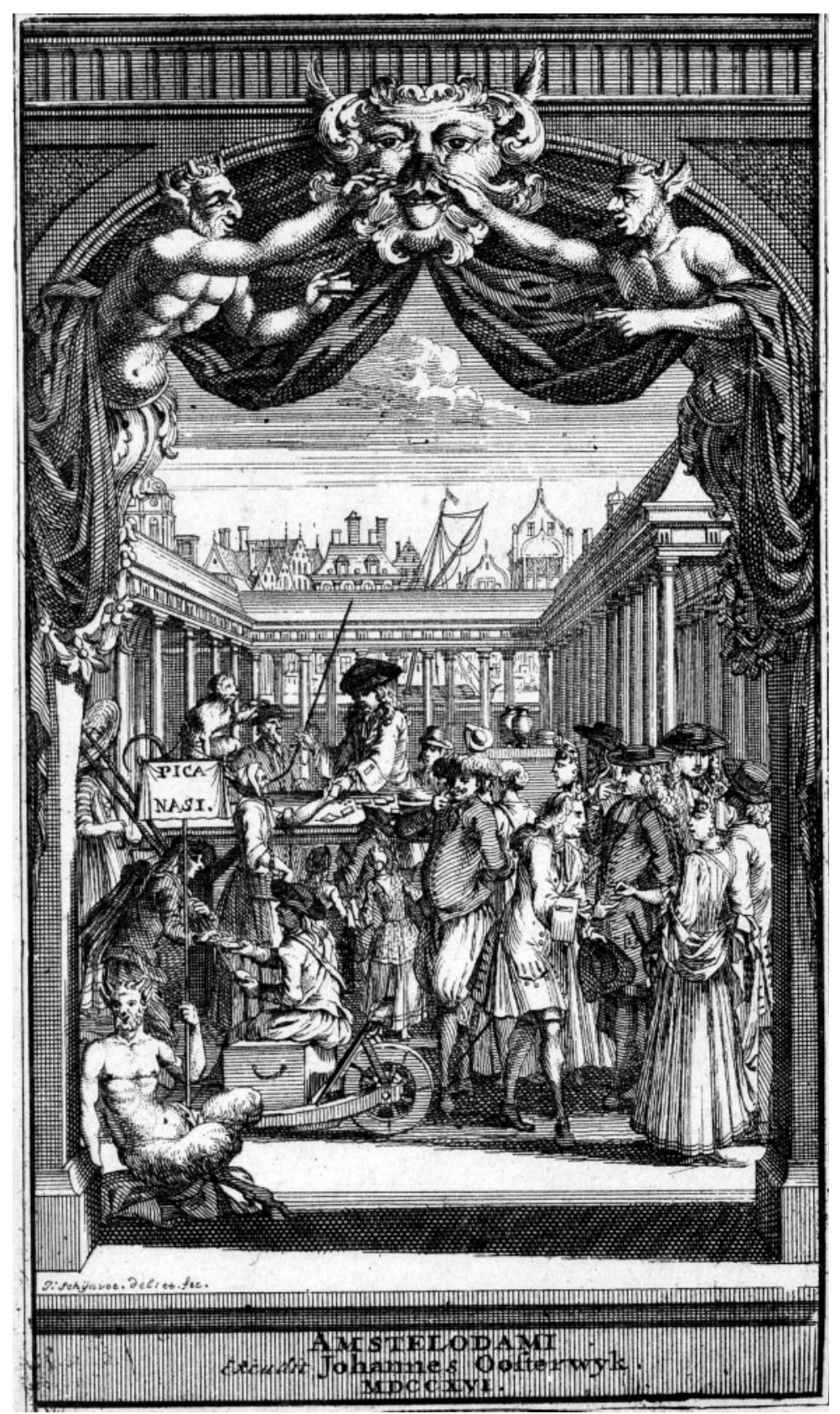

Figure 2: Frontispiece to Johann Cohausen, Dissertatio satyrica physico-medico-moralis de pica nasi, sive tabaci sternutatorii, Amsterdam, J Oosterwyk, 1760. Even the ornament decorating the top of the arch is taking snuff. (By permission of the Wellcome Library, London.) 


\section{Anna Marie Roos}

his work, which made his satire all the more effective. Cohausen simply modified the traditional literary conceit of satirizing the search for the philosophers' stone with a humorous treatment of more current iatrochymical analyses of respiration and longevity, taking these ideas to outrageous conclusions. Ironically, because of Cohausen's skilfulness in presenting medical concepts in the Hermippus, further analysis of the intellectual context of his ironic treatise also aids our understanding of early modern theories of longevity and iatrochymistry.

\section{The Basis for the Hermippus}

The title of the Hermippus redivivus was probably based upon two references. Hermippus was an ancient one-eyed comic active during the Peloponnesian War who parodied Homer and wrote satiric verse, a genre of which Cohausen was fond. ${ }^{6}$ In the Hermippus, the reader was treated to a "redivivus" or redux of such humour, so Cohausen in his title was thus indicating to his audience his satiric intent. Cohausen also claimed that the title was based upon an ancient and most certainly not genuine inscription said to have been found in the seventeenth century in Rome. Being an amateur classicist himself, the physician correctly claimed the inscription was included in Thomas Reinesius's magisterial Syntagma inscriptionum (1682). But Cohausen conveniently did not mention that Reinesius deduced from its philology that it was probably a fraud, and not worthy of any serious concern from classicists (Figure 3 ). ${ }^{7}$ The inscription in question was therefore well suited for satire, and it read:

\section{Æsculapio et Santitati \\ L. Clodius Hermippus \\ Qui vixit annos CXV. Dies V. \\ Puellarum anhelitu \\ Quod etiam post mortem ejus \\ Non parum mirantur Physici \\ Jam posteri sic vitam ducite. ${ }^{8}$}

Gruter, Syntagma inscriptionum antiquarum cumprimis Romæ veteris, quarum omissa est recensio in vasto Jani Gruteri opere cujus isthoc dici possit supplementum: opus posthumum ... cum commentariis absolutissimis et instructissimis indicibus nunc primum editum, Leipzig and Frankfurt, Johann Fritschens Erben, 1682, p. 156. Reinesius says of the inscription, "it is laughable, and unworthy of any concern, from one who understands the pagan world". ("Jocularia est, et indigna cuiusquam curâ, sapitque seculum semibarbarum.")

${ }^{8}$ Cohausen, 'Preface' to Hermippus redivivus, op. cit., note 7 above, p. 4. Literally, "L. Clodius Hermippus, who lived 115 years and 5 days on the breath of girls, which after his death astonishes physicians, dedicates this to Æsculapius and to health. Those of you who follow, extend your life in a similar way." 


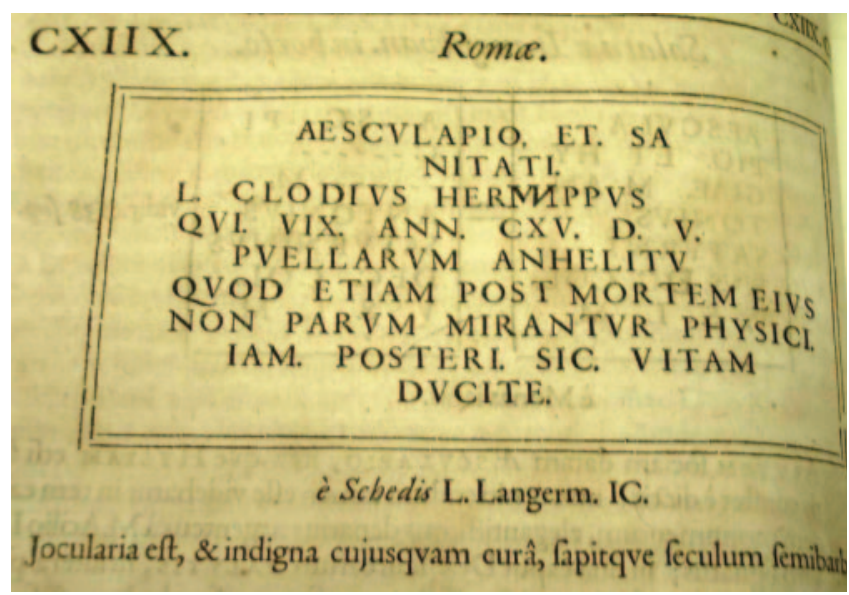

Figure 3: The inscription and subsequent disclaimer of its authenticity in Thomas Reinesius and James Gruter, Syntagma inscriptionum antiquarum cumprimis Romae veteris, Leipzig and Frankfurt, Johann Fritschens Erben, 1682, p. 156. (Photo by the author. With permission from the Harris Manchester College Library, Harris Manchester College, University of Oxford.)

Translated, it described one L Clodius Hermippus who lived 115 years and five days by imbibing the breath of young women, which had life-restoring qualities. In his work, Cohausen speculated about Hermippus' life, surmising that he was the prefect and teacher in an orphanage or school for girls sponsored by the Roman government. ${ }^{9} \mathrm{He}$ described in detail how Hermippus spent most of the day in the rooms of the orphanage with the children, telling them stories designed to promote virtue, and playing and joking with them. A large fire was built in the morning to rarefy the air before the children arrived, so he would get the most benefit out of the little girls' breath, and, in damp weather, the rooms were perfumed so malicious smells would not enter; there was also a garden surrounding the orphanage with plants that quickened the vital spirit and prolonged life with their odours. ${ }^{10}$ In an eighteenth-century German edition of the work, the engraving on the frontispiece likewise illustrated Hermippus surrounded by a classroom of children, one little boy sitting on his right knee reading a book (Figure 4). ${ }^{11}$

\footnotetext{
${ }^{9}$ Ibid., p. 25. "Conjicio itaque eum in Orphanotrophio Romano puellari seu Gymasio quodam Virgineo ...".

${ }^{10}$ Ibid., pp. 47-8: "Adjacebat Paedatrophio hortus amoenissimus, in quo florum herbarumque, quae magnum vitae longiori praestant subsidium gratissimis odoribus Spiritus vitales recreantes, et quibus etiam indies conclave exornabant puellae solertiores, uberrimus erat proventus. In hunc quotidie serenius arridente aura cum universo juvencularum grege secedebat et exspaciabatur Hermippus, comitantibus singulas suis pupis inter quas sine cura degebat, ne unam quidem hanc curam sumens, qua solicitus curaret,
}

qua potissimum diligentia curas effugeret. Sine quo uno tanquam omnium praesidiorum vita, omnia ad producendam vitam ad hibita emori cum Platonicis indicabat. Hi cum puellis jocabatur, ludebat, saltabat, cantillabat, et ludiera puerilia exercebat vere repuerascens."

${ }^{11}$ Johann Heinrich Cohausen, Frontispiece, Der wieder lebende Hermippus, oder curioese physicalisch-medicinische Abhandlung von der seltenen Art sein Leben durch das Anhauchen Junger-Mägdchen bis auf 115. Jahr zu verlängern ... aus dem Lateinischen übersetzt, Sorau, 1753. 


\section{Anna Marie Roos}

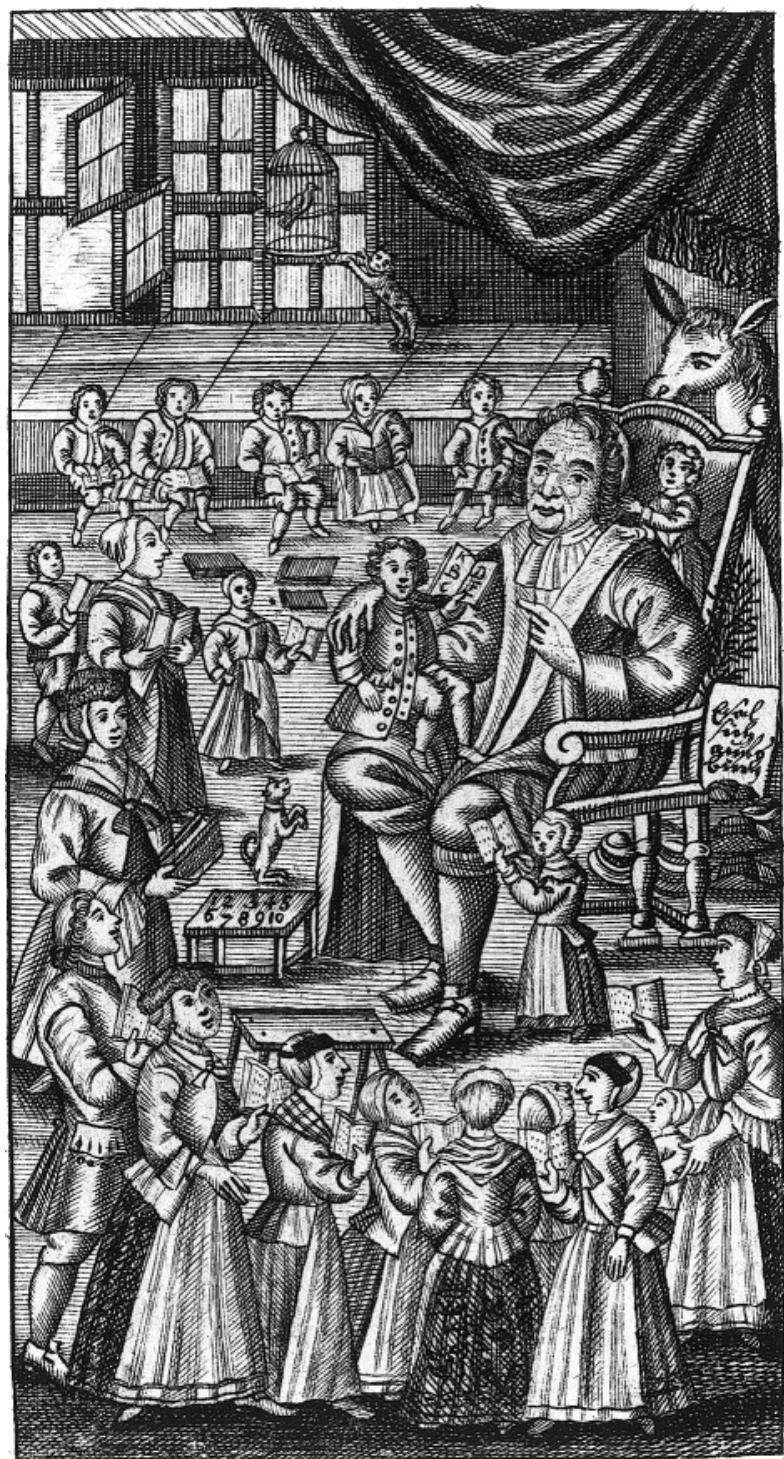

Figure 4: Frontispiece to Cohausen's Der wieder lebende Hermippus, Sorau, 1753. A youthfullooking Hermippus is surrounded by children learning their lessons. (By permission of the British Library.)

The Hermippus was a commercial success, mentioned by the Journal des Scavans, and translated into English in 1743 by John Campbell (1708-75), a Scottish historian and political writer. Campbell's text was re-translated into French by Monsieur de la Place in 1789 , and "it is this that is known and considered by many people as the work of the German physician"; some later readers even thought that Campbell had written the 


\section{Johann Heinrich Cohausen's Hermippus Redivivus}

Hermippus in its entirety. ${ }^{12}$ Samuel Johnson said that it was a "very entertaining account of the hermetic philosophy and as furnishing a curious history of the extravagances of the human mind". ${ }^{13}$ Isaac D'Israeli described Campbell's book as a "curious banter on the hermetic philosophy and the universal medicine; the grave irony is so closely kept up, that it deceived for a length of time the most learned. Campbell assured a friend it was a mere jeu-d'-esprit". ${ }^{14}$ William Godwin (1756-1836) later mentioned that the Hermippus was the inspiration for his novel St. Leon (1800). ${ }^{15}$ According to William Osler, Campbell's translation "had a rapid sale and induced many people to adopt the notion of prolonging life by inhaling the breath of young persons. A physician took lodgings in a boardingschool after having read the essay."16

However, in its attempts to be entertaining, Campbell's translation added even more ludicrous claims and content to Cohausen's original work, augmenting it with legends of longevity from the medieval period, deleting passages that might offend the sensibilities of female readers, and embellishing it even more in a 1749 edition. ${ }^{17}$ These additions were not surprising, for Campbell was well known to be skilful at fictitious autobiography and satire, writing, for instance, The travels and adventures of Edward Brown, Esq., formerly a merchant in London, in 1739. The "description given in it by three Arab brothers ... of a strayed camel, which they had never seen, may have suggested to Voltaire the similarly constructive description of the dog and horse of the queen and king of Babylon in 'Zadig" ". ${ }^{18}$ Johnson also remarked that "Campbell is not always rigidly careful of truth ... he once told me that he drank thirteen bottles of port at a sitting ... [and] you could not entirely depend on any thing he told you in conversation". ${ }^{19}$ Whether aided by port or not, Campbell did his translation of Cohausen's Hermippus quite loosely, transforming Cohausen's more subtle medical satire, which contained a number of serious examinations of theories of longevity, into a completely outrageous flight of fancy designed to maximize profits at the booksellers. ${ }^{20}$

\footnotetext{
${ }^{12}$ Beauvois, op. cit., note 2 above, pp. 89-90; William Godwin believed the Hermippus was authored by Campbell. See William Godwin, St. Leon: a tale of the sixteenth century, 2 vols, Dublin, P Wogan,

G Burnet, P Byrne, W Porter, W Jones, 1800, vol. 1, Preface, p. 1; Johann Heinrich Cohausen, Hermippus redivivus, or, The sage's triumph over old age and the grave, transl. John Campbell, London, J Nourse, 1744.

${ }^{13}$ James Boswell, The life of Dr. Johnson, 2 vols, London, J M Dent and Sons, 1933, vol. 1, p. 258.

${ }^{14}$ Isaac D'Israeli, Curiosities of literature, 6 vols, London, E Moxon, 1834, vol. 2, p. 102. Isaac was the father of the politician Benjamin Disraeli.

${ }^{15}$ Godwin, op. cit., note 12 above, vol. 1, p. 1 . In Godwin's moralistic tale, the main character, the Count St Leon, who suffers from a gambling addiction, learns the secret of the philosophers' stone from a stranger. His immortality and wealth causes him to lose his wife, suffer from a case of mistaken identity, and to be
}

estranged from his son, nearly leading him to fight a duel against him at the end.

${ }^{16}$ William Osler, Bibliotheca Osleriana: a catalogue of books illustrating the history of medicine and science, Oxford, Clarendon Press, 1929, p. 215.

${ }^{17}$ Beauvois, op. cit., note 2 above, pp. 89-90.

${ }^{18}$ Dictionary of National Biography (hereafter $D N B$ ), Oxford University Press, 1995, CD-Rom version, s.v. 'John Campbell, LLD'; John Campbell, The travels and adventures of Edward Brown, esq; formerly a merchant in London, London, A Bettesworth and C Hitch, 1739.

${ }^{19}$ Boswell, op. cit., note 13 above, vol. 1, p. 176. Johnson, however, did say that Campbell never "lied with pen and ink".

${ }^{20}$ According to his $D N B$ entry, Campbell was charging nearly 2 guineas a sheet to write the last of his published works, so his business strategy was certainly successful. 


\section{Cohausen's Theories of Longevity: The Iatrochemical Influence of Jean Baptiste van Helmont}

Campbell's reinvention of the Hermippus also overshadowed Cohausen's earlier and entirely scholarly treatises on longevity and iatrochemistry, such as the Tentaminum physico-medicorum curiosa decas (1699), written in response to the publication of a rival physician. Born in Hildesheim in Lower Saxony, Cohausen studied medicine in Frankfurt-on-the-Oder, and became physician to the Bishop of Munster in 1717, retiring to private practice in Vreden. ${ }^{21}$ In 1693 , when Cohausen, having finished his studies, established his medical practice near Munster, Conrad Berthold Behrens, a physician in Hildesheim and member of the Académie Césareo-Léopoldine, composed a treatise on longevity. ${ }^{22}$ It was dedicated to the prime minister of the Bishop of Munster, in the hope of patronage. However, after much anticipation and excitement in the bishop's court about the secrets that the book would reveal, there was a bit of disappointment. Behrens argued that God determined there was a fixed lifespan for humans and that prolonging life was not possible. This led to his subsequent exile from court. ${ }^{23}$ Hoping to make a name for himself, Cohausen penned his own work on longevity, the Tentaninum physico-medicorum curiosa decas, and presented it to Frederick Christian, the Bishop of Munster. ${ }^{24}$ This opportunistic work made his career, as the bishop subsequently showed him great favour, making him his primary physician and a provincial physician for the jurisdictions of Ahaus and Horstmar. ${ }^{25}$ Ensuring he would not have the fate of Behrens, Cohausen warned his readers, "May he who is preparing to read this text not believe that I am rather presumptuous for promising him the extended age of Nestor". ${ }^{26}$ Rather, in ten chapters Cohausen analysed the different means of prolonging life, including animal, mineral, and vegetable preparations; his central tenet was that the tree of life was placed in the terrestrial paradise by God, and that in our postlapsarian state, it is possible to recover it via chemical medicine and the arcanum or life elixir; as Urszula Szulakowska has demonstrated, the "tree of life" schematized "the means to obtain the philosophers' stone and its nature". ${ }^{27}$ In his approach in the Decas, Cohausen directly imitated the ideas of the chymist and physician van Helmont, who in his own writings on the extension of life wrote: "Arcanums ... do exceed the Powers of Nature, even as Art doth very often overcome Nature: And that is not only true in Secrets which heal Diseases; but also in the Tree of Life, which restores

\footnotetext{
${ }^{21}$ Allgemeine Deutsche Biographie, online http:// mdz1.bib-bvb.de, accessed 3 Oct. 2005, s.v. 'Cohausen, Johann Heinrich'; Dictionnaire historique de la médecine ancienne et moderne (Mons, 1778), s.v. 'Cohausen, Jean-Henri'. The relatively few biographical resources on this physician were also noted by Beauvois, op. cit., note 2 above, p. 1 .

${ }^{22}$ Beauvois, op. cit., note 2 above, p. 23.

${ }^{23}$ Ibid., p. 24.

${ }^{24}$ Ibid., pp. 24, 26; Johann Heinrich Cohausen, Tentamium physico-medicorum curiosa decas, de vita humana, Cosfeld, Johann-Bartholomeus Stein, 1699. This treatise was published at Cohausen's own expense indicating his desire for patronage.
}

\footnotetext{
${ }^{25}$ Jodocus Hermann Nünning, Commercii litterarii dissertationes epistolicæ historico-physico-curiosæ ...J. H. Nunningii et J.H. Cohausen . . cum utriusque historica bibliographia et præfatione epicritica S. E. E. Cohausen, 3 vols, Frankfurt am Main, 1746-54, vol. 1, p. 123, as quoted by Beauvois, op. cit., note 2 above, p. 26.

${ }^{26}$ Cohausen, 'Preface', to Tentaminum physico-medicorum, as quoted by Beauvois, op. cit., note 2 above, p. 24.

${ }^{27}$ Beauvois, ibid., pp. 24-5; Urszula Szulakowska, 'The tree of Aristotle: images of the philosophers' stone and their transference to alchemy from the fifteenth to the twentieth century', Ambix, Nov. 1986, 33 (2/3): $53-77$, p. 58.
} 


\section{Johann Heinrich Cohausen's Hermippus Redivivus}

defective Nature: Therefore the Ordination of that tree, is the Preservation of Life, with a certain kind of renewing of Youth". ${ }^{28}$ As we will see in the Hermippus, Cohausen would claim that the breath of young women was a very arcanum, and proposed that the vapour from their breath be collected in trumpets, and subsequently distilled to produce an elixir of life. The Decas, though not initially written for purposes of satire but of patronage, would provide a useful resource when Cohausen wrote the Hermippus over forty years later.

Although he would not publish another work on longevity until the Hermippus (he did have an extended version of the Decas in manuscript form), Cohausen continued to evince a strong interest in publishing survey works based on the medicine, iatrochemistry and alchemy of van Helmont. In his work on fevers, Archeus febrium faber et medicus, Cohausen remarked of van Helmont that he was a man sent by God to advance the reformation of medicine. ${ }^{29}$ Indeed Cohausen supported Helmont's theory of the irritation of the archeus or the "internal efficient cause" or life force of the body as the cause of fever; the archeus was resident in the stomach, and when the archeus perceived that the body was poisoned by disease, it became agitated and attempted to drive out the cause of the illness via a fever. ${ }^{30}$ In van Helmont's words, fever was thus a "perturbation of the archeus of life", or as the historian Walter Pagel said of van Helmont's position, "fever is not a disease, but a symptom that indicates the war waged by nature against disease". 31 Thus in the Archeus febrium, Cohausen prescribed van Helmont's special regime of barley, oat, and rice gruel, which was easy on the stomach and would help restore the archeus to its proper order. ${ }^{32}$ In this work, Cohausen may have also been following the ideas of the German physician Johannes Doleaus, who in his popular Encyclopaedia medicinae theoreticopracticae (1684) adopted van Helmont's notion of the archeus and fevers. ${ }^{33}$

Cohausen also wrote the Helmontius ecstaticus, a survey of van Helmont's remedies, and an explication of an ecstatic vision that van Helmont experienced. This vision comprised the frontispiece, which showed van Helmont receiving the gemma rosae or the "perfect ruby", the philosophers' stone, as well as the alchemical mystery of the ignisaquae, the alkahest or the universal solvent from a messenger of God (Figure 5). ${ }^{34}$ The alkahest was believed to dissolve gold and every other substance, its use could help one to

\footnotetext{
${ }^{28}$ Jean Baptiste van Helmont, Van Helmont's works, transl. John Chandler, London, Lodowick Lloyd, 1664, p. 753.

${ }^{29}$ Johann Heinrich Cohausen, Archeus febrium faber et medicus, Amsterdam, Salomon Schouten, 1731, p. 8: "Quibus sic statuminatus patescit definitionem Helmontii Viri ad reformanda \& exornanda artis dogmata à Deo electi satis esse concinnam"; see also Beauvois, op. cit., note 2 above, pp. $58-9$.

${ }^{30}$ Cohausen, ibid., p. 2: "Archeum hunc in stomacho veluti throno residere credidit Helmontii. In eo namque veluti peculiari suo sensorio omnium ingestorum, sive alimenta sive Medicamenta, sive venena sint, utilitates atque noxas percipit et distinguit, suasque indignationes, furores, angorem, metum, variasque morborum ideas, concipit, et mediante fluidorum solidorumque mechanismo regulares motus in irregulares et inordinatos commutando, varios
}

morbos et febres ipsas concitat." See also Beauvois, op. cit., note 2 above, p. 68 . As pointed out by an anonymous reviewer, Paracelsus was the first physician to discuss the archeus, a concept which van Helmont expanded.

${ }^{31}$ Walter Pagel, Joan Baptista van Helmont: reformer of science and medicine, Cambridge University Press, 1982, p. 161.

${ }^{32}$ For more about the archeus, see Van Helmont's works, op. cit., note 28 above, p. 1009.

${ }^{33}$ Antonio Clericuzio, Elements, principles, and corpuscles: a study of atomism and chemistry in the seventeenth century, Dordrecht, Kluwer, 2000, p. 197, describes J Dolaeus, Encyclopaedia medicinae theoretico-practicae, Frankfurt am Main, 1684.

${ }^{34}$ Johann Heinrich Cohausen, Helmontius ecstaticus, Amsterdam, Salomon Schouten, 1731, p. 301. 


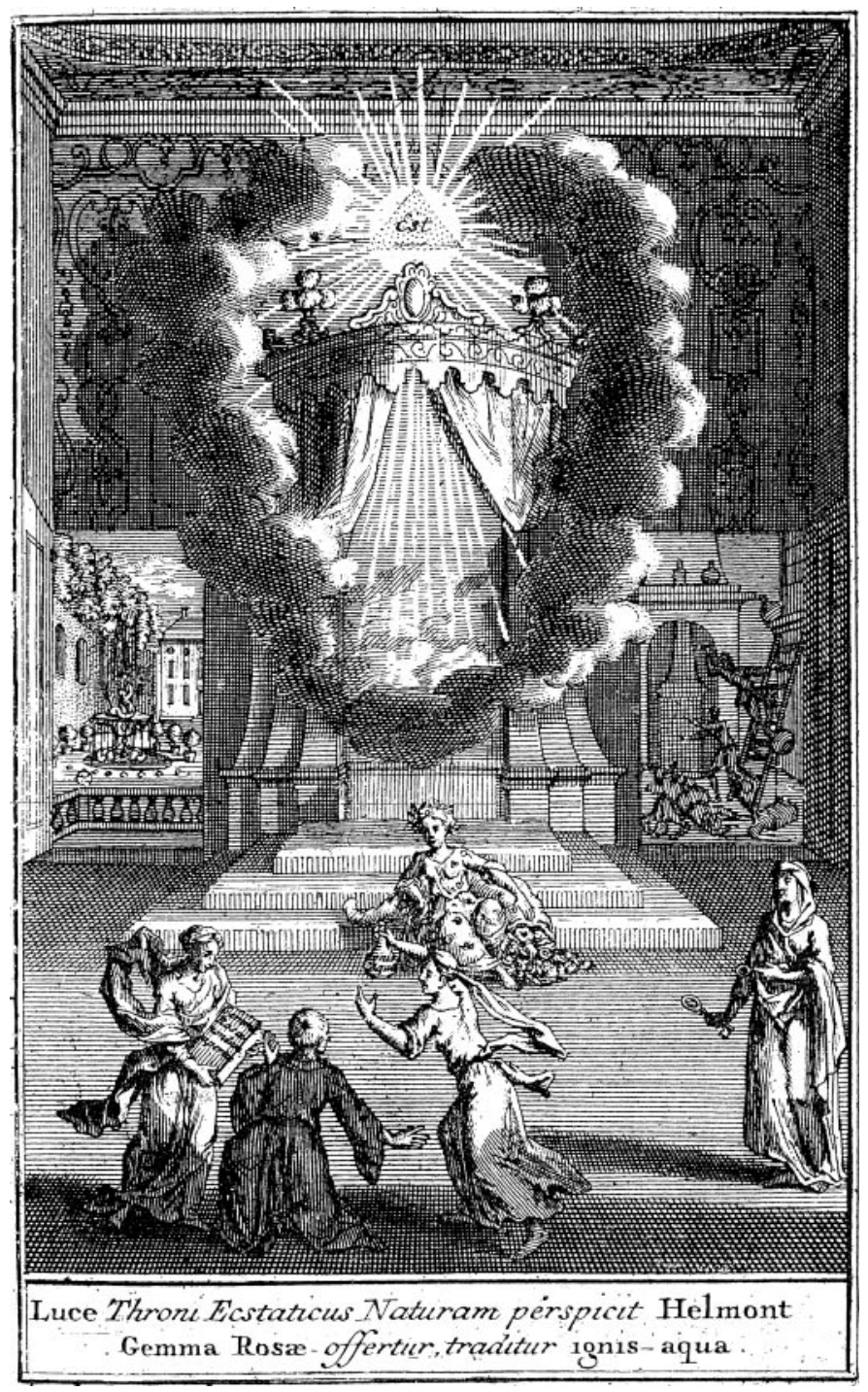

Figure 5: Frontispiece to Cohausen's Helmontius ecstaticus, Amsterdam, Salomon Schouten, 1731. The figure with the open book proffers the gemma rosae or philosophers' stone to van Helmont, while the other gives him the flask with the ignis-aquae or alkahest. In the background we see a fountain of water to the left, and the fires of the alchemical laboratory to the right. The figure on the left represents the kneeling van Helmont with the "clavis" or key to alchemical wisdom. "Est" or "it is", the revealed light of God's wisdom, and nature, crowned with laurels and in a garment covered with alchemical symbols, lies resplendent on the steps of the altar. (By permission of the British Library.) 


\section{Johann Heinrich Cohausen's Hermippus Redivivus}

understand matter at its most basic, and it was supposed that it would possess invaluable medicinal qualities. As William Newman and Lawrence Principe have remarked, early modern chymists considered the alkahest " 'the immortal solvent', for after it has completed the dissolution and analysis of a compound body into its constituents, it can be separated from the dissolved substances in the same quantity and quality as it was first employed. The alkahest's action is based upon the exceedingly minute size and homogeneity of its corpuscles", 35

Salts, particularly volatile ones that were reactive when heated or possessed a distinct odour, were usually candidates for the alkahest, a premise with which Cohausen agreed, stating: "Liquori alkahest ex subjecto salino". ${ }^{36}$ As Norma Emerton has commented, in the early modern period, "as the instrument of the form, as embodiment of the generative seed and spirit, and as the transmitter of mineral qualities including crystallinity, salt became the formative principle par excellence". ${ }^{37}$ Salts not only looked homogenous in their material form when visually examined, but the chemical reactivity of volatile salts made them seem candidates for the universal solvent. ${ }^{38}$ Some chymists, like Johann Rudolph Glauber (160470), thought the alkahest was nitre or potassium nitrate because its products could be very acidic and very basic, both of which were corrosive. ${ }^{39}$ For instance, nitre could be distilled with fuller's earth to make nitric acid (spirit of nitre or volatile nitre), a strong acid or, it could be "fixed" by burning it with charcoal, producing potassium carbonate, a very powerful base. Unfortunately for Glauber, he recombined his volatile nitric acid and his fixed potassium carbonate and recognized that he had produced simple nitre reconstituted, so nitre was obviously not a universal dissolvent. ${ }^{40}$ Van Helmont, realizing that the search for the alkahest was difficult, offered his followers an alternative, "the volatilization of fixed alkalies - particularly salt of tartar [in modern terms, probably potassium carbonate or $\mathrm{K}_{2} \mathrm{CO}_{3}$ — - to produce a solvent with powers akin to, though still inferior to, those of the alkahest". ${ }^{41}$ Powerful alkalis can indeed dissolve a good deal of substances via their corrosive nature, and are involved in saponification or soap-making. Cohausen again

\footnotetext{
${ }^{35}$ William R Newman and Lawrence M Principe, Alchemy tried in the fire: Starkey, Boyle, and the fate of Helmontian chymistry, University of Chicago Press, 2002, p. 137.

36 "Liquid alkahest originates from salt", Cohausen, op. cit., note 34 above, p. 301.

${ }^{37}$ Norma E Emerton, The scientific reinterpretation of form, Ithaca, Cornell University Press, 1984, p. 214.

${ }^{38}$ There were many early modern works on the medical and chemical efficacy of volatile salts. The French court physician Joseph Du Chesne's (15441609) Liber de priscorum philosophorum verae medicinae materia (1603) and his Ad veritatem hermeticae medicinae ex Hippocratis veterumque decretis ac therapeusi (1604) had extensive commentaries on salt chemistry and medicine, including a focus on nitre. Du Chesne's works were later translated into English by Thomas Tymme to create The practice of chymicall and hermeticall physicke (1605), which introduced Paracelsian salt
}

chemistry to England. See Allen Debus, The English Paracelsians, Chicago University Press, 1968. Other seventeenth-century works such as Otto Tachenius' Hippocrates chymicus, discovering the ancient foundations of the late viperine salt (London, 1677; Latin. 1666), as well as the works of Nicaise Le Fèvre (1610-69) discussed volatile salts. Le Fèvre was professor of chemistry at the court of Charles II of England, and a Fellow of the Royal Society, and his work on salts was the Traicté de la chymie (Paris, 1660). The English translation was entitled A compleat body of chymistry (London, 1664).

${ }^{39}$ Kathleen Ahonen, 'Johann Rudolph Glauber: a study of animism in seventeenth-century chemistry', $\mathrm{PhD}$ thesis, University of Michigan, 1972, p. 107, n. 59, as cited in Newman and Principe, op. cit., note 35 above, p. 242.

${ }^{40}$ Newman and Principe, op. cit., note 35 above, p. 242.

${ }^{41}$ Ibid., p. 138. 


\section{Anna Marie Roos}

followed van Helmont's lead, and in an unpublished manuscript, the 'Sal tartari volatile intricassimum extricatum ... de praeparatione salis tartari volatilisati, vice-alcahestini' (The Intricate Extraction of the Volatile Salt of Tartar, . . the Vice-Alkahest), he described his attempts to volatilize the rather non-evaporative potassium carbonate. ${ }^{42}$

Cohausen was interested in the volatilization of salts not only so as to produce an alkahest, but because volatile salts in the blood were thought by van Helmont to "be the conserver of the body". ${ }^{43}$ Van Helmont originated the study of volatile salts in a primarily iatrochemical and medical context. In his analysis of the chemistry of the blood in the Ortus medicinae (1648), he claimed that venous blood, having given nourishment to the organs of the body, was made volatile and converted into gas which was breathed out. ${ }^{44}$ This conversion of the venous blood into breath was thus done chemically, and concerned with the production of chemically non-reactive fixed and reactive volatile salts. The historian Walter Pagel further explains van Helmont's theories of blood chemistry:

Fixed salt is alkali; its particles are stable and form a deposit when a substance containing it is liquefied by heat. In settling down[,] it "snatches" particles of less subtle nature-so-called sulphurous particles-which are thus incorporated in the deposit. The fixed salt being unable to fix all the sulphur particles, the rest, which have escaped being snatched, follow their natural tendency to become volatile and in their turn force some of the salt to evaporate with them. Thus, volatile salt is generated. When heated in an open vessel all salt contained in the substance evaporates. This is what happens to the ... [venous] blood in the ... lung, that is where it is in contact with the air. All its salt has become volatile whereby it is disposable by the breath. ${ }^{45}$

Thus van Helmont believed that volatile salts composed the vital spirit or breath of both animals and plants, which was resolved in the heart by fermentation "into a salt air, and enlightened by life". ${ }^{46}$ In other words, volatile salts were thought to compose a vital spirit made of arterial blood transformed in the heart by fermentation into a salt air that was expelled by breathing.

Cohausen followed suit in the Hermippus, claiming "the most expert anatomists know for certain that out of a [young and] sound body, a lively flying salt will be breathed out, and this breath will have a vital strength and balsamic capacity or at the least a powerful mechanical elasticity which communicates vigour, according to the precepts of the philosophers" ${ }^{47}$ He then stated, "It is true according to the opinion of Helmont ... that the breath penetrates the whole bodily system, even to the hairs, catching up volatile salts in its passage". 48 Thus, because their blood circulation was vigorous, the breath of youth

\footnotetext{
${ }^{42}$ A list of Cohausen's unpublished manuscripts can be found in Jodocus Hermann Nünning, op. cit., note 25 above, and a description of them is provided in Beauvois, op. cit., note 2 above, pp. 118-33.

${ }^{43}$ Van Helmont's works, op. cit., note 28 above, p. 744 .

${ }^{44}$ Pagel, op. cit., note 31 above, pp. 88-90.

${ }^{45}$ Ibid., pp. 89-90.

${ }^{46}$ Debus, op. cit., note 4 above, p. 58; see also Van Helmont's works, op. cit., note 28 above, p. 196.

${ }^{47}$ Cohausen, Hermippus redivivus, op. cit., note 7 above, p. 12: "Unde è contrario dilucescit, si è corpore
}

sano, vivido sale volatili turgido remittatur, ipsamque, quo apud recentiores plerosque Anatomicos expertissimos hodie certum est ... vel virtutem balsamico vitalem juxta doctrinam Philosophorum, vel juxta principia mechanica saltem vim elasticam potentiorem, adeoque motum vivaciorem alterius corporis sanguinis solidisque communicare."

${ }^{48}$ Ibid., "Si vera foret Francisci Mercurii Helmontii sententia Alphabet Nat. Colloq. 4 de occulta anhelitus circulatione in abdomine ceu centro corporis, omnibusque membris, ne capillis quidem exceptis, quis dubitet eundem de corporis universi proprietate participare." 


\section{Johann Heinrich Cohausen's Hermippus Redivivus}

brimmed with salts; when inhaled by the aged, this salty breath would prolong life. ${ }^{49}$ The breath was thus a chemical arcanum.

In his reliance on van Helmont in his satire, Cohausen was following the theories of iatrochemical physicians and natural philosophers in the latter half of the seventeenth century. ${ }^{50}$ Influenced by van Helmont's belief that the breath of man and animals contained volatile salts, Robert Boyle (1627-91) wrote in his Suspicions about some hidden qualities of the air (1674) that the atmospheric air may contain such salts. Boyle's colleague Daniel Coxe (1640-1730), a physician and Fellow of the Royal Society, claimed "the Air, which is as I could fully demonstrate, impregnated with a Volatil Salt ... partly expired from Animals [and Plants] during their life". ${ }^{51}$ An addendum to Luigi Cornaro's treatise on longevity (1740), which Cohausen referenced in the Hermippus, contained excerpts from the Transactions of the Royal Society written in the seventeenth century that attributed life-giving properties to salts in the breath; this same excerpt was also published in a History of cold bathing (1715), so it must have been a reasonably pervasive anecdote. The excerpt related that there was a:

Man in the North [of England] of an extream Age; ... he lay on a Pad on the Ground in a dark smoaky tatter'd Cottage ... with a little Cow lying by him, chewing the Cud ... I ask'd him what that Cow serv'd for, with her Mouth so near him? He answer'd, for Refreshment; for, said he, the Breath of the Cow is a Cordial, and much refreshes me when I am faint ... As to being comforted with the Breath of the Cow, 'tis highly rational to believe it; for the breath was warm, and must emit with it some volatile Salts, and fragrant Particles, analogous to our own Spirits. I have heard several Shepherds ... say that in rouzing of their Herds from their Rest in a Morning, the Steams not only of their Bodies, but even the Effluvia and Scent of their Dung and Urine has been grateful and refreshing, from those salubrious volatile Salts that they draw in with their Breath in their SheepFolds, and Cow-houses, early in a Morning before the Beams of Light and Heat exhale them, and rob them of the best Nose-gay in the World. ${ }^{52}$

\section{The Role of Insensible Perspiration in Longevity and Gendered Exhalations}

After his discussion of saline particles in the breath, Cohausen then explained in the Hermippus how the exhalations and inhalations of the body played a role in prolonging life, particularly the emissions from the pores of the skin. Van Helmont claimed that

\footnotetext{
${ }^{49}$ Ibid., ". . . et copia spirituum turgeant, sed et quod nonnulli praetendunt, adhuc initiis suis seminalibus proximiores plurimum balsami radicalis, quod tamen singulis annorum periodis magis imminuatur, obtineant patet effluvia ex illarum corpore emanantia eiusdem plane esse conditionis."

${ }^{50}$ Antonio Clericuzio, for instance, has illustrated the importance of a vital saline spirit to seventeenthcentury English physicians in his article, 'The internal laboratory: the chemical reinterpretation of medical spirits in England (1660-1680)', in Piyo Rattansi and Antonio Clericuzio (eds), Alchemy and chemistry in the 16th and 17th centuries, Dordrecht, Kluwer, 1994 pp. 51-83.
}

\footnotetext{
${ }^{51}$ Robert Boyle, Suspicions about some hidden qualities of the air with an appendix touching celestial magnets, London, W G for M Pitt, 1674, pp. 59-60; Daniel Coxe, 'A continuation of Dr Daniel Coxe's discourse ... touching the identity of all volatil salts', Philos. Trans., 1674, 108: 169-82, on p. 172.

${ }^{52}$ Luigi Cornaro, Sure and certain methods of attaining a long and healthful life, Dublin, Richard Gunne, 1740, pp. 58-59. This account was also published in John Floyer and Edward Baynard, $\Psi \mathrm{YXPO} \Delta \mathrm{OY} \Sigma \mathrm{I}^{\prime} \mathrm{A}$ or, The history of cold bathing, both ancient and modern in two parts, 4th ed., London, William Innys, 1715, pp. 409-10.
} 


\section{Anna Marie Roos}

volatile salts were emitted through insensible perspiration, and Cohausen argued that the pores were engaged continually in the aeration of the blood, inhaling and exhaling the surrounding atmosphere, taking up and discharging atmospheric particles from the circulatory system; if the surrounding atmosphere was healthy, the body would benefit, but if virulent, the body could become diseased. ${ }^{53}$ Cohausen's assertion was of course a version of the miasma theory of disease, discussed by natural philosophers such as Robert Boyle with regard to the effects of effluvia and the salubrity of the atmosphere on health. ${ }^{54}$ In his Elementa chemiae, the Leiden physician Hermann Boerhaave also analysed the virtues of plants diffused through the air and their subsequent medicinal effects; for instance postulating that the effluvia of the poppy procured sleep, and the vapour of the yew was thought to be deadly to those who slept under it; van Helmont in his discussion of human breath, proclaimed that odours were more efficacious than liquid medicines, "seeing that the Spirit of our life, since it is a Gas, is most mightily and swiftly affected by any other Gas, to wit, by reason of their immediate co-touchings". ${ }^{55}$ Cohausen reasoned if the smells of vegetables had such powerful effects, animal odours in the form of breath and sweat should even have stronger results. Therefore, one could imbibe not only the breath of healthy young people, but also be benefited by their perspiration exhaled through the skin.

To continue the formulation of his argument, Cohausen utilized the work of Sanctorius (1561-1636), a Paduan physician, on insensible perspiration. Sanctorius wrote that perspiration was "absolutely necessary to the well being of a Human Body-[Its production was] occasion'd by the constant Circulations of the Animal Fluids, and the forcible

\footnotetext{
${ }^{53}$ Jean Baptiste van Helmont, Ortus medicinae, Amsterdam, Elsevier, 1648; reprint, Brussels, Culture et Civilisation, 1966, pp. 178-92; Cohausen,

Hermippus redivivus, op. cit., note 7 above, pp. 51-2: "According to Hippocrates and other the nobles of Medicine, the human body when healthy perspires through the open pores of the skin. [This is] because of the incessant motion and the continuous circular course of the blood in which small particles are incessantly emitted. Sanctorius weighed the mass of these excretions of the body which bodies previously excreted ... These effluvia give out a scent through transpiration and are of the nature of the body from which they are emitted, a sickening and harmful scent from those that are unhealthy, and a vigorous and sound scent from the youthful, and but when examined this emanation is humid and unctuous, and as one sweats it likewise condenses into a damp and fatty substance. Likewise the breathing human body has pores and the absorbent vessels in the skin, through which lifeless bodies accept the outward animated corpuscles of exhalations. Undoubtedly, the pores of the skin are engaged in the aeration of the blood, inhaling the surrounding atmosphere and then exhaling it again, reinforcing vital movements, or if the air is virulent, destroying life." ("Corpus humanum juxta

Hippocratem caeterosque Medicinae proceres perspirabile est, quatenus per poros cutis in sanitate
}

patulos ob continuum liquidorum motum sanguinis perpetua circulatione attenuati particulae sive effluvia incessater emittuntur, quae juxta staticen Sanctorii quascunque alias corporis excretiones mole et aliquot librarum pondere ... Effluvia haec transpirata, seu per transpirationem emissa corporum suorum redolent naturam; et uti ex aegrotantibus et cacochymicis insalubria et noxia, sic ex juvenilibus vegetis ac sanis non tantum vivida, sana et volatilia, sed et humidounctuosa excernuntur, quemadmodum et ipse sudor, qui ex transpiratis condensatis constat, humidus quoque et pinguis est. Humanum corpus inspirabile quoque est, idest habet poros et vasa absorbentia in cutis ... Indubitatem est aërem effluviis resertum per cutis spiracula ingredi et sanguini ac succo nervoso se insinuare, motusque vitals aut roborare, aut etiam, si virulentus fit, perssumdare.")

${ }^{54}$ Robert Boyle, An experimental discourse of some unheeded causes of the insalubrity and salubrity of the air, London, Samuel Smith, 1690, p. 169. Though he does not explicitly refer to van Helmont in this context, it is also possible Cohausen could have been influenced by Helmontian writings on the weapon salve and magnetism, which postulated an action-at-adistance mechanism of disease. See 'Of the magnetick or attractive curing of wounds', in Van Helmont's works, op. cit., note 28 above, pp. 756-92.

${ }^{55}$ Van Helmont's works, note 28 above, p. 110. 


\section{Johann Heinrich Cohausen's Hermippus Redivivus}

Contractions and Attritions of the Solids". 56 Those parts of the fluids and solids that were not necessary for the nourishment of the body flew out through the pores of the skin and mouth, meaning that it was necessary for there to be a "proportionate Recruit by daily Food". 57 By measuring the amount of insensible perspiration in the body and regulating one's diet, and keeping the outflow of sweat and consumption of food at a constant level, one could regulate and preserve one's health. ${ }^{58}$ Sanctorius then argued that as the body aged, the solids and fibres grew hard, contractions in the tissues slowed and stopped, perspiration halted, and death resulted. In other words, the bodily tissues and relevant organs would lose their tonic motion. Tonus was a wide-ranging concept in early modern medicine originally postulated by the Stoics and Galen, and held not only by Sanctorius but by other physicians such as Boerhaave and George Stahl. ${ }^{59}$ Tonic motion referred to the mechanism by which "the blood circulation ... delivered harmful matters to the excretory organs, and ... the colatory structure of the organs that filtered out those matters. As the body's putrefaction [and aging] continued, tonic motion worked vigilantly to hold it in check".60

Cohausen agreed, writing in the Hermippus that "The body ... is made up of fluid and solid materials, and life depends on the incessant movement of the fluids, especially the systole and diastole, but if the movement of fluid stops, the body will die". ${ }^{61}$ However, Cohausen argued that the bodily fluids were constantly agitated not only through the blood circulation, but by the operations of air currents which penetrated the body through the pores and mouth. Although old age would mean gradual stoppage of fluid movement and obstruction of the pores, if the circulation of the fluids was maintained by the infusion into the pores and mouth of fresh vital forces in the air, such as from the close proximity of young people, then life could be extended. ${ }^{62}$

\footnotetext{
${ }^{56}$ Sanctorius, Medicina statica: being the aphorisms of Sanctorius, translated into English with large explanations by John Quincy, London, William Newton, 1712 , p. 1.

${ }^{57}$ Ibid.

${ }^{58}$ Ibid., p. 19.

${ }^{59}$ Jerome Bylebyl, 'The medical side of Harvey's discovery: the normal and the abnormal', in Jerome Bylebyl (ed.), William Harvey and his age: the professional and social context of the discovery of the circulation, Baltimore, John Hopkins University Press, 1979, pp. 28-102, on pp. 40-1; See also Hermann Boerhaave, Institutions in physick, transl. J Browne, 2nd ed., London, Jonas Browne, 1715, p. xvi; Boerhaave wrote, "Therefore these two kinds of Motion, viz. a Pulse which exerts its Power in the Vessels and the Heart, and drives from the Centre to the Circumference, and the Tone which is seated in all the Fibres, membranous and muscular Parts ... if these are in a right State and in due Strength, Equality and Temperment, the Blood is received into the Parts equally and without Impediment, and from the same, a due Quantity is expell'd in due time, the Secretions naturally follow, and so the Business of Health is perform'd".

${ }^{60} \mathrm{Ku}-\mathrm{Ming}$ (Kevin) Chang, 'Motus tonicus: George Ernst Stahl's formulation of tonic motion and
}

early modern medical thought', Bull. Hist. Med., 2004, 78: 767-803, p. 789.

${ }^{61}$ Cohausen, Hermippus redivivus, op. cit., note 7 above, p. 52: "Notum est corpus humanum esse machinam pnevmatico-hydraulicam ex fluidis atque solidis contextam, ejusque evexiam et vitam in horum continuo motu atque circulo consistere, liquidorum autem motum à solidorum motu tonico, systole atque diastole unice dependere, ita ut hisce integris ac salvis vita constet, cessantibus atque ablatis pereat."

${ }^{62}$ Ibid., pp. 52-3: "Certum porro fluida corporis humani in se spectata, quatenus indies renovantur et per alimenta restaurantur, quam diutissime et vel ultra aevum durare posse, eorum tamen motum tandem necessario imminui ac demum tolli duntaxat et vitio solidorum, quatenus haec tractu temporis, et longo annorum cursu paulatim indurantur, exarescunt, rigida sicque immobilia evadunt, unde tono et motu cessante confectarium quoque est fluida remorari et tandem penitus subsistere. In qua fibrarum ariditate, duritie, inflexilitate et ad vividum motum ineptitudine senectutis ratio formalis consistit, quam proin veteres in siccitate et frigiditate collocarunt ... Ex quibus demum concludo, si quis posset solida in sua mollitie, flexilitate ac consequenter justo tono ac motu conservare, eum 


\section{Anna Marie Roos}

One way to keep the pores of the skin open and performing well to maintain tonus was via oil, a technique for longevity utilized by the ancients. Cohausen related Pliny's account of Pollio, a soldier of the Emperor Augustus, who when asked how he had managed to live over a hundred years replied: "Melle intus, foris Oleo", or "honey within, oil without". 63

As well as anointing oneself on the outside, Cohausen felt it was possible to "oil" the pores of the body from the inside by inhaling specifically young female breath, as he claimed women were more oily or fatty than males. He supported this theory with the writings of the ancient Macrobius who claimed that in funeral piles it was important to lay one fatty female body next to six male bodies in a great pyre, so that the male bodies would be more speedily consumed. ${ }^{64}$ After a facetious anecdote, where Cohausen claimed that the physician Fabricius knew of a lady who emitted sparks when she combed her hair, he more seriously refers the reader to his publication Lumen novum phosphoris accensum (1717) for evidence of the latent heat and fire of women. ${ }^{65}$

Cohausen's Lumen was a serious scholarly effort submitted to the Bordeaux Academy of Science (established in 1703) in competition for a prize granted by the duc de la Force of 300 livres for the best answer to a proposed question. In this case, the prize committee requested an explanation for the cause of light from phosphorus, a topic of much interest in both continental and English natural philosophy; in 1674, Henning Brandt of Hamburg first obtained phosphorus from the "Microcosmic Salt" a name given to phosphates from urine excreted from the microcosm of the body, and Boyle also wrote two works about his early experiments with phosphorus, entitled The aerial noctiluca (1680) and The icy noctiluca (1682). ${ }^{66}$ Although it failed to win the prize, Cohausen's Lumen was a compilation of all the theories that attempted to explain the phenomena of phosphorescence; the first part of the work analysed natural phosphors of the air, sea, and land, and the second section compiled instances of luminescence of plants and animals, such as in glow-worms, as well

quoque posse avertere senectutem, et sic vitam ultra centum pluresque annos facile protrahere." Cohausen refers the reader to his Decas for further discussion of tonus.

${ }^{63}$ Ibid., pp. 53-4: “. . . qui ut memorat Verulamius ad annum tricentesimum aetatem produxisse fertur seu ut alii referunt Pollionis veterani militis apud Caesarem Augustum, qui centesimum annum longe excesserat. Qui rationem rogati, quomodo vigorem corporis tanto tempore conservarint, respondisse dicuntur: Melle intus, foris Oelo - Plinius" 1.2. c 24.]

${ }^{64}$ Ibid., pp. 54-5: “Corporis vero puellaris perspirabile non duntaxat humidum est, sed et unctuosum, idest ex aqua et oleo constans, ideoque naturam et vim obtinens humectandi et emolliendi siccas rigidasque corporis senilis fibras, quo diuturniori motui, contractioni dilatationi, et fluidorum impulsui sufficiant.... Dixi perspirabile corporis puellaris esse unctuosum, alii vapores oleosos seu halitus sulphureos appellant, quia corpora faeminea prae virilibus, et consequenter etiam puellaria prae puerilibus majore scatent unctuositate, quod experientia antiquos quoque
Romanos docuerat, quibus ut scribit Macrobius cadavera comburendi ritum recensens, solenne erat senis virorum cadaveribus muliebre adjicere, qui persuasum erat unius adjectu quasi natura flammei ceatera virorum corpora rapidiori foco absumi."

${ }^{65}$ Ibid., pp. 55-6: “. . . . et apud Jo. Fabri in Palladio Chymico puella inter pectendum è capite ingremium ignis scintillas stellarum instar excutiens ... Fiendi modum et causam Lumen meum novum phosphoris accensum sufficienter detexit." Johann Heinrich Cohausen, Lumen Novum Phosphoris Accensum, Amsterdam, Joannem Oosterwyk, 1717.

${ }^{66}$ E Newton Harvey, A history of luminescence: from the earliest times until 1900, Memoirs of the American Philosophical Society, vol. 44, Philadelphia, American Philosophical Society, 1957, pp. 151, 154; Beauvois, op. cit., note 2 above, pp. 43-51, passim; Robert Boyle, The aerial noctiluca or some new phoenomena, and a process of a factitious self-shining substance, London, Tho. Snowden, 1680; idem, New experiments, and observations, made upon the icy noctiluca, London, printed by R E for B Tooke, 1682. 


\section{Johann Heinrich Cohausen's Hermippus Redivivus}

as artificial phosphors such as the Bononian stone. In the third section of the Lumen, Cohausen praised the artificial "hermetic phosphorus" discovered in 1673 by Christian Adolph Balduin, a magistrate in Saxony; it was an impure calcium nitrate (perhaps containing some sulphur) made from chalk and nitric acid, believed to be a potential alkahest. ${ }^{67}$ In his attempts to explain luminescence, Cohausen remarked in the Lumen, "there is in all things a certain salt, which is nothing other than potential fire", and he included observations on the development of molecules of fire that existed in the human body, including descriptions of some cases of spontaneous combustion; he believed them most prevalent in women, supposedly occurring after they imbibed large amounts of brandy or spirits. ${ }^{68}$ From ideas such as these, Cohausen affirmed in the Hermippus that "with these examples it is sufficiently understood that latent fire is plainly in superabundance in women's bodies bringing forth copious vital heat". 69

Cohausen's comments were an interesting inversion of the Aristotelian premise of matter and spirit dualism between male and female. In the pre-modern era, men were typically seen as hot, spiritous, the givers of form to matter. On the other hand, Aristotle claimed that women, who were of moist and cold complexions, were shorter lived than males, and that they were merely material and closer to the animal world. ${ }^{70}$ As Guerrini has commented, "The ideal female of Vesalius, in images which persisted for centuries, was literally more material than the male, being fleshy and voluptuous in contrast to the tautly muscled ideal man". ${ }^{71}$ However, in Cohausen's medical work of the Enlightenment, the human body was less a vessel of Aristotelian humours than a machine fired by an internal chemical combustion engine; with this advent of iatrochemistry and Cartesianism, Cohausen turned Aristotelian gendered assumptions on their heads, a not uncommon event in satirical works which often invert accepted principles. Through their very materiality, their

\footnotetext{
${ }^{67}$ Harvey, op. cit., note 66 above, pp. 155, 321. Balduin's first name sometimes appears as Christoph.

${ }^{68}$ Cohausen, op. cit., note 65 above, p. 25 , as quoted in Harvey, ibid., p. 155; Beauvois, op. cit., note 2 above, p. 47 , mentions Cohausen's anecdote about brandy and spontaneous combustion in the Lumen novum. Anecdotes about latent fire in the body, and speculations as to its cause were prevalent in the seventeenth and eighteenth centuries. For instance, the physician Thomas Willis related in his Practice of physick (1681), "for we have known in some endued with a hot, and vapourous blood, when they have put off their inner garments at night going to bed near a fire of Candle, a very thin and shining flame to have shewn itself, which hath possessed the whole inferiour region of the Body. The reason of which affection seems wholly the same, as when the evaporating fume of a Torch just put out is again inflamed by a light inkindling, and manifestly argues that another flame, the root of this extrinsick one, lyes hid within the Body". Thomas Willis, Dr. Willis's Practice of physick, being all the medical works of that renowned and famous physician ... London, T Dring, C Harper, and J Leigh, 1681, p. 32. As Clericuzio has indicated,
}

Willis believed that heat was generated "by the reaction of particles of nitre coming from the air and mixing with sulphur contained in the blood", op. cit., note 50 above, pp. 65-6. For a survey of early modern ideas of spontaneous combustion, see Jan Bondeson, A cabinet of medical curiosities, London, I B Tauris, 1997, pp. 1-25.

${ }^{69}$ Cohausen, Hermippus redivivus, op. cit., note 7 above, p. 56: "Hoc loco saltem scire sufficit, quod lux illa veluti calor summe attenuatus superabundantem in corporibus faemineis ignis vitalis copiam prodat."

${ }^{70}$ Lynn Thorndike, 'Two other passages $D e$ complexionibus', Isis, June 1963, 54 (2): 268-9, p. 269.

${ }^{71}$ Anita Guerrini, 'The hungry soul: George Cheyne and the construction of femininity', Eighteenth-Century Studies, 1999, 32 (3): 279-91, p. 280; See also Londa Schiebinger, The mind has no sex?: women in the origins of modern science, Cambridge, MA, Harvard University Press, 1989, ch. 6; Maryanne Cline Horowitz, 'Aristotle and woman', $J$. Hist. Biol., 1976, 9: 183-213; Joan Cadden, The meanings of sex difference in the Middle Ages, Cambridge University Press, 1993. 


\section{Anna Marie Roos}

fatty flesh, women produced spirit, the ethereal vital breath. Guerrini has commented that over the course of the eighteenth century, "the medical definition of the female changed from being primarily physical to being primarily emotional: from body to spirit". ${ }^{72}$ Cohausen witnessed this transition, and utilized it for his medical and satirical purposes.

If women were perceived as more ethereal and sensitive in their nature as the eighteenth century progressed, there was the danger that the "sensitive were also sensual, and more given to the pleasures of the flesh, conforming to the older view of women as animal-like". ${ }^{73}$ In the Hermippus, Cohausen adhered to this caution, noting that it was not the breath of any woman that was ethereal and life-giving, but only those women who were healthy, young and chaste; virgins were particularly effective in their life-giving powers. ${ }^{74}$ In answer to an objection raised by his colleague Bishop Nünning, who in his own attempt to add hilarity to the Hermippus exhorted Cohausen to explain why Solomon with all his many wives had not lived a long life, Cohausen claimed it was because Solomon was surrounded by women in a harem, and their breath was tainted by lustful relations. ${ }^{75}$ Cohausen also entreated his readers never to marry an old woman, as she would absorb all the vital principles from one's lungs. The young man who married a rich old spinster in hope of gaining money would trade his life, as she would become youthful, and he prematurely aged. ${ }^{76}$ Old women were "like cats, whose breath is poisonous to life", a reference to the age-old connection of cats to crones, witchcraft and female sexuality. ${ }^{77}$ As Cohausen explained, as women aged and became more withered and dry, their breath became more noxious, and more representative of their supposed animalistic natures.

\footnotetext{
${ }^{72}$ Guerrini, op. cit., note 71 above, p. 279.

${ }^{73}$ Ibid., p. 285.

${ }^{74}$ Here Cohausen may have been influenced by Roger Bacon's recommendation that the touch of girls, beautiful song, and the sight of beauty could give longevity. See Bruce Moran, Distilling knowledge: alchemy, chemistry, and the scientific revolution, Cambridge and London, Harvard University Press, 2005 , p. 24. My thanks to one of the anonymous reviewers for this reference.

${ }^{75}$ Cohausen, Hermippus redivivus, op. cit., note 7 above, ch. 3, pp. 37-48 is entitled: "Resolvuntur geminae autori ab Amico propositae Quaestiones: 1. Cur non longaevior fuerit Salomon, cui tot ex integra puellarum legione singulis horis fuerunt Nympharum Aspirationes?" or "Here some questions are solved which were proposed by a friend of the Author: 1 . Why was it that Solomon did not have a long life, as every single hour he was surrounded by the breath of a legion of young women?"

${ }_{76}$ Ibid., pp. 61-2: "Sic passim vetulis os oblinunt juvenes, ut aurea haereditate potiantur. Interim vetulae, quibus putridus oris halitus, et impuri, exsucci squalidique corporis nequam est Spiritus,
}

pravo contactu faedoque commercio maritos juvenes brevi tempore emarcere faciunt, et in senium propero gradu praecipitant". "Thus everywhere young man defile [themselves] with the breath of their elderly wives to obtain a golden inheritance. Meanwhile the elderly wives, with their unclean breaths from their squalid bodies decay with their crooked touch their youthful husbands in a short time, causing their precipitous aging."

${ }^{77}$ Ibid., pp. 63-4: Tanta est cati domestici malignitas ex oculis et ore spirans (nam et ejus cerebrum homini toxicum habetur) ... ac hecticam immaturamque mortem inciderint... . Sed nec minus periculum est, si quis uxorem vetulam concubinam habeat, quae juvenilis vitae flammam satis reluctantem non quidem statim difflare et dissipare, paulatim tamen instar cati imminuere et extinguere potest]; Roger Chartier, 'Texts, Symbols, and Frenchness', J. Mod. Hist., Dec. 1985, 57 (4): 682-95, has an analysis of cat symbols in the early modern period in its analysis of Robert Darnton's 'Great cat massacre'. See Robert Darnton, 'The great cat massacre, 1730', History Today, Aug. 1984, 34: 7-15; Pierre Roudil, 'Dieu ou 


\section{Johann Heinrich Cohausen's Hermippus Redivivus}

\section{Conclusion}

From Cohausen's advice to bottle female breath, to marry young wives, as well as his admonition to schoolteachers not to smoke in the classroom, as they were denying themselves the volatile salts in the breath of their charges, it would be evident to most readers that they were in the midst of an effective satire which drew on medical theories of the day for a humorous end. To continue the joke, much in the manner of Thomas More's Utopia, Cohausen used the satirical device of including a series of encomiums and letters praising the Hermippus. One letter was from his friend Bishop Nünning, who had earlier critiqued Cohausen's work with his example of Solomon; another was from his eldest son, Bernard, also a physician of some note who published a work on the chyle; and there was a concluding "epigramma votivum" from Salentinus Ernest Eugenius Cohausen, the nephew of our author, doctor to the troops of the Elector Archbishop of Cologne, and active correspondent with scientific societies. ${ }^{78}$

After this extensive display of learned praise, Cohausen could not maintain the pretence any longer, and finally admitted in the last few pages that the premise of the Hermippus was a "lusus satyricus", Hermippus himself a fictional character. Cohausen launched his career by penning a work that did not promise any secrets of immortality, and, ironically, he ended it in the same vein, no doubt disappointing his more gullible readers much as the work by Behrens had disappointed the members of the Bishop of Munster's court forty years earlier. Like Behrens, Cohausen proclaimed in a concluding verse that longevity was not to be found in the breath of girls or the philosophers' stone, but rather "Sed fato et Fortunae salutari, Causis plerumque eventuum occultis": aging was due to the outcome of fortune, with unknown causes and outcomes. ${ }^{79}$

In the Helmontius ecstaticus, Cohausen praised van Helmont's hermetic vision of receiving the alkahest and the philosophers' stone, and in the Decas, the physician proclaimed it was humanity's purpose to search for the lost tree of life. Now, at the end of his own life, in his conclusion to the Hermippus, Cohausen continued his verse satire with a poem dedicated to the Emerald Tablet of Hermes Trismegistus, which alchemists claimed held the secret of the philosophers' stone and immortality. ${ }^{80}$ Pictorial representations of the Emerald tablet contained the Latin acrostic for the volatile salt vitriol, thought to be a possible source of the philosophers' stone: "visita interiora terrae rectificando invenies occultum lapidem" - "visit the interior of the earth, by rectifying you will find the hidden stone". Cohausen's satirical reference to a volatile salt that supposedly held the secret of immortality could not be a more fitting end to his work. Newman has noted that "only around the beginning of the eighteenth century did transmutational alchemy come to be strictly segregated from chemistry, and even then there was overlap in some quarters." 81 During his career, which ended in the early Enlightenment, Cohausen witnessed and

diable: le chat dans L'histoire', Histoire Magazine, 1983, 36: 66-73.

${ }^{78}$ Cohausen, Hermippus redivivus, op. cit., note 7 above, p. 84. For a complete description of Cohausen's relatives, see Beauvois, op. cit., note 2 above, pp. 134-9.

\footnotetext{
${ }^{79}$ Cohausen, Hermippus redivivus, op. cit., note 7 above pp. 86, 90 .

${ }^{80}$ Ibid., p. 86

${ }^{81}$ William R Newman, Promethean ambitions: alchemy and the quest to perfect nature, University of Chicago Press, 2004, p. xiii.
} 
demonstrated in the Hermippus the gradual transformation of alchemical principles into chemical ones; what were formerly serious precepts became subjects for humour and derision. As John Campbell wrote in the preface to his version of the Hermippus, "there is in this Dissertation, such a Mixture of serious Irony, as cannot but afford a very agreeable Entertainment to those who are proper Judges of Subjects of this Kind, and who are inclined to see how far the Strength of human Understanding can support philosophical Truths against common Notions, and vulgar Prejudices". ${ }^{82}$ We can only agree, for Cohausen's satire was worth its salt indeed.

${ }^{82}$ Campbell, 'Preface' to Cohausen, op. cit., note 12 above, pp. v-vi. 